\title{
Composition, structure, and physicochemical characteristics of pigeon pea (Cajanus cajan) starches from Indonesia
}

\author{
NUR ROHMAH LUFTI A'YUNI ${ }^{1,2}$, YUSTINUS MARSONO ${ }^{1}$, DJAGAL WISESO MARSENO ${ }^{1}$, \\ PRIYANTO TRIWITONO ${ }^{1, \bullet}$ \\ ${ }^{1}$ Department of Food and Agricultural Product Technology, Faculty of Agricultural Technology, Universitas Gadjah Mada. Jl. Flora No. 1, Bulaksumur, \\ Sleman, Yogyakarta 55281, Indonesia. Tel./fax.: +62-274-589797, `email: triwitono@ugm.ac.id \\ ${ }^{2}$ Politeknik Pembangunan Pertanian Yogyakarta-Magelang. Jl. Kusumanegara No. 2, Umbulharjo, Yogyakarta 55167, Indonesia
}

Manuscript received: 26 March 2021. Revision accepted: 25 July 2021.

\begin{abstract}
A'yuni NRL, Marsono Y, Marseno DW, Triwitoyo P. 2021. Composition, structure, and physicochemical characteristics of pigeon pea (Cajanus cajan) starches from Indonesia. Biodiversitas 22: 3430-3439. Information on the characteristics of pigeon pea (Cajanus cajan (L.) Millsp.) starch would provide a scientific basis for developing its application. However, data about characteristics of pigeon pea starch, especially from the Southeast Asia region, has been limited. This study determined the composition, structure, and physicochemical characteristics of pigeon pea starches from three different Indonesian regions, i.e., Bali, Yogyakarta, and West Nusa Tenggara (NTB). We also investigated the potential application of Indonesian pigeon pea starches. Pigeon pea starch was extracted using a wet method, and then pigeon pea starch was characterized. The yield of pigeon pea starches ranged from 29.83-31.68\%. Pigeon pea starches showed a significant difference $(\mathrm{P}<0.05)$ in amylose content $(54.74-58.51 \%)$, relative crystallinity $(24.20-28.97 \%)$, waterbinding capacity $(0.70-0.76 \mathrm{~g} / \mathrm{g})$, oil binding capacity $(0.55-0.58 \mathrm{~g} / \mathrm{g})$, swelling power $(13.19-14.52 \mathrm{~g} / \mathrm{g})$, and solubility $(9.48-11.15 \%)$. The pasting properties (except for final viscosity) and thermal properties (except for onset temperature and gelatinization enthalpy) differed significantly. Granules of pigeon pea starch were oval to elliptical, with a mean granule diameter of 18.41-19.98 $\mu \mathrm{m}$. According to X-ray diffraction patterns, pigeon pea starches showed $\mathrm{C}_{\mathrm{A}}$ type, contained orthorhombic and hexagonal crystals. Pigeon pea starches also showed the same FTIR spectra. The results revealed that the differences in pigeon pea growing locations affect pigeon pea starch's composition and physicochemical properties. The highest amylose content and lowest relative crystallinity were found in Yogyakarta pigeon pea starch. In the future, our findings could be used to develop pigeon pea starch for various food applications.
\end{abstract}

Keywords: Microstructure, physicochemical, pigeon pea, starch

\section{INTRODUCTION}

Starch is a complex microparticle consisting of two primary components, amylose and amylopectin, usually accompanied by water, lipids, phospholipids, soluble and insoluble fiber, and some minerals (Rodriguez-Garcia et al. 2021). Starch is a renewable substance with some biological properties like biocompatibility, nontoxicity, and biodegradability. Because of these starch properties, starch can be used in various industrial sectors, including tissue engineering, medicine, and food processing, such as confectionery, sauces, restructured meat products, puddings, and low-fat products (Chen et al. 2015; Wani et al. 2016). The global starch market is projected to reach US\$ 75.4 billion in 2022, from a prediction of US\$ 53 billion in 2016. Therefore, a new starch source is required (Acevedo et al. 2019). Legumes with a 25 to $50 \%$ starch content are a potential source of starch (Alcázar-Alay and Meireles 2015). Legume starch contains more amylose, dietary fiber, and resistant starch than cereal and pseudocereal starches (Nissar et al. 2017). Therefore, further research on legume starches is required to develop food and non-food applications (Lima et al. 2017).

Pigeon pea (Cajanus cajan (L.) Millsp.) is a legume that provides a starch source. Pigeon pea is widely grown in both tropical and subtropical areas worldwide (Lawal
2011). Pigeon pea has a starch content of $57.5 \%$ (Tayade et al. 2019) and a starch yield of 29.7-49.3\% (Hoover et al. 2010). Previous studies on pigeon pea starch physicochemical characteristics have been conducted using pigeon pea from India (Hoover et al. 1993; Kaur and Sandhu 2010; Narina et al. 2014) and Argentina (Acevedo et al. 2019). Kaur and Sandhu (2010) reported that pigeon pea starch had a low hydrolysis index and high resistant starch, indicating that it was highly resistant to digestion. Acevedo et al. (2019) reported that pigeon pea starch is a potent starch source to provide tailor-made properties to food and industrial applications because of its high gel stability and amylose content. Research on pigeon pea starch from the Southeast Asia region has been limited. Previous studies had only focused on the characterization of various pigeon pea starch varieties. Therefore, there is a shortage of data on pigeon pea starch's composition, structure, and physicochemical characteristics from different growing locations. Differences in the environment (soil type, temperature, atmospheric composition, and meteorological factors) where plants grow can affect the biosynthesis and starch properties (Hood-Niefer et al. 2012; Beckles and Thitisaksakul 2014).

Research on the physical and microscopic characteristics of pigeon pea starch from Indonesia has been performed by Widowati and Buckle (1991). 
Unfortunately, they only reported the water absorption, solubility, gelatinization temperature, gel strength, and starch granule morphology. Widowati and Buckle's study just used pigeon pea from Pasuruan and Yogyakarta. There has been no research into the characteristics of pigeon pea starch from the Bali and West Nusa Tenggara (NTB). In Yogyakarta, Bali, and NTB, pigeon pea is widely grown; therefore, they are readily available. Its use, however, was only limited to consumption as a vegetable. Information on pigeon pea starch's physicochemical characteristics can provide essential scientific knowledge to develop pigeon pea starch application in non-food and food fields, mainly to diversify food products. This study aimed to determine the composition, structure, and physicochemical characteristics of pigeon pea starch from three different Indonesian regions: Bali, Yogyakarta, and NTB, and to investigate the potential application of Indonesian pigeon pea starch.

\section{MATERIALS AND METHODS}

\section{Materials}

Pigeon pea seeds (local varieties) were obtained from local farmers in three different Indonesian regions, i.e., Buleleng of Bali, Gunungkidul of Yogyakarta, and Lombok Timur of West Nusa Tenggara (NTB). Pigeon pea was harvested in April-May 2019 (Yogyakarta and NTB) and June 2019 (Bali). The characteristics of the growing locations in 2019 are shown in Table 1.

\section{Extraction and isolation of starches}

Extraction and isolation of pigeon pea starch were conducted according to Hoover et al. (1993) with modifications from Ratnaningsih et al. (2016). Pigeon pea seeds were split by grinder then steeped in distilled water with a seed: water ratio of 1: 5 for 12 hours at room temperature. The seed coats of pigeon pea were removed by manual abrasion. The steeping water was replaced every 3 hours to discard the pigeon pea seed coats. The swollen legumes were ground together with distilled water $\left(4^{\circ} \mathrm{C}\right)$ using a blender. The starch slurry was filtered through a filter cloth. The residual pulps were ground two more times, then filtered. The starch suspension was allowed to settle at $4^{\circ} \mathrm{C}$ for 12 hours before the supernatant was discarded. The starch sediment was dissolved in distilled water $\left(4^{\circ} \mathrm{C}\right)$, adjusted to $\mathrm{pH} 11.0$ using $0.1 \mathrm{~N} \mathrm{NaOH}$, steeped for 3 hours at room temperature, and then the supernatant was discarded. This treatment was performed six times. The starch sediment was redissolved in distilled

Table 1. Characteristics of the growing locations of pigeon pea

\begin{tabular}{lccc}
\hline Climate & Bali & Yogyakarta & NTB \\
\hline Temperature $\left({ }^{\circ} \mathrm{C}\right)$ & 27.80 & 25.94 & 28.69 \\
Humidity $(\%)$ & 78.93 & 81.46 & 72.61 \\
Number of precipitation $(\mathrm{mm})$ & 1838.80 & 2121.40 & 1717.90 \\
Number of rainy days (day) & 140 & 130 & 135 \\
Duration of sunshine $(\%)$ & 62.85 & 78.55 & 67.32 \\
\hline
\end{tabular}

Source: BPS-Statistics Indonesia (2020) water, adjusted to $\mathrm{pH} 7.0$ using $0.1 \mathrm{~N} \mathrm{HCl}$, then was rinsed with distilled water. The starch sediment was dried for 24 hours at $40^{\circ} \mathrm{C}$, ground, sieved using 100 mesh, packed in aluminum foil with silica gel, then put into a container, and kept at room temperature until analysis.

\section{Determination of chemical composition}

The proximate composition was analyzed based on the AOAC method (1995) for determining moisture (No. 925.09), ash (No. 923.03), lipid (No.920.39), and crude protein (No.920.87). The protein content was measured using the Kjeldahl method by multiplying crude nitrogen content by conversion factor 6.25 . The amylose content was determined using Juliano's method (1971). The starch purity was determined as the total starch percentage using the direct acid hydrolysis method (AOAC 1995).

\section{Determination of starch color}

The starch color was determined using chromameter CR-400 (Minolta, Japan). Results were presented in the L* (lightness), $\mathrm{a}^{*}\left(+\mathrm{a}^{*}\right.$ value is redness; $-\mathrm{a}^{*}$ value is greenness), and $b^{*}\left(+b^{*}\right.$ value is yellowness; $-b^{*}$ value is blueness) color space. The whiteness index was calculated based on this equation (Zhu et al. 2009):

$$
\text { Whiteness index }=100-\sqrt{(100-L)^{2}+a^{2}+b^{2}}
$$

\section{Determination of swelling power and solubility}

Swelling power and solubility determination were conducted referring to the method of Gunaratne et al. (2011). Starch was weighed (100 mg, dry basis), placed in a centrifuge tube, and added $10 \mathrm{~mL}$ of distilled water. The centrifuge tube was put on a vortex for $10 \mathrm{~s}$ and incubated at $85^{\circ} \mathrm{C}$ for $30 \mathrm{~min}$ in a water bath shaker. The tubes were quickly cooled to room temperature and centrifuged for 30 min at $2000 \mathrm{~g}$. The supernatant was separated, and the sediment was weighed (Ws). The supernatant was dried in an oven $\left(105^{\circ} \mathrm{C}\right)$ to steady weight $\left(\mathrm{W}_{1}\right)$. The swelling power (SP) and solubility (S) were calculated based on this equation:

$$
\begin{aligned}
& \mathrm{SP}=\frac{\mathrm{Ws}}{\text { [sample weight } \mathrm{x}(10036-\mathrm{S}) \mathrm{g} / \mathrm{g}} \\
& \mathrm{S}=\frac{\text { W1 }}{\text { sample weight }} \times \mathbf{1 0 0 \%}
\end{aligned}
$$

\section{Determination of water-binding capacity (WBC) and oil binding capacity (OBC)}

Water and oil binding capacity (WBC and OBC) determinations were performed based on Yousif et al. (2012). One gram of sample was mixed with $15 \mathrm{~mL}$ of distilled water in the centrifuge tube. The tube was vortexed for $2 \mathrm{~min}$, then centrifuged for $20 \mathrm{~min}$ at $1250 \mathrm{~g}$. After centrifugation, the clear supernatant was poured and removed. Water-binding capacity was measured as the gram of water bound by a gram of dry sample. The same method was conducted to determine oil binding capacity by replacing distilled water with $10 \mathrm{~mL}$ of corn oil. Oil binding capacity was measured as the gram of oil bound by a gram of dry sample. 


\section{Determination of granule morphology}

The starch granule morphology was determined using Scanning Electron Microscopy (SEM) (Phenom Pro-X, Netherlands) based on the method of Liu et al. (2015). Before observation, the sample was mounted on the stub specimen and coated with gold. The analysis was carried out in a $15 \mathrm{kV}$ voltage accelerating vacuum. For imaging particle shape, the SEM instrument was equipped with a backscattered electron detector. The sample was observed under 3000× magnification.

\section{Determination of particle size}

The particle size of starch granules was measured using a Particle Size Analyzer (PSA LA-960, Horiba, Japan), referring to the method of Joshi et al. (2013). The sample was added with purified water as a dispersion medium. The slurry was mixed, put into the cuvette, and then put into the PSA's cuvette holder. The measurement duration was 120 s.

\section{Determination of pasting properties}

The pasting properties of starches were determined using Rapid Visco Analyser (RVA-S4, Newport Scientific, Australia) with Thermocline for Windows 3 software. Approximately $3.0 \mathrm{~g}$ of starch (14\% moisture basis) was added to the RVA canister, followed by $25 \mathrm{~mL}$ of distilled water (adjusted to compensate for a $14 \%$ moisture basis). The starch slurries temperature was kept at $50{ }^{\circ} \mathrm{C}$ for $1 \mathrm{~min}$ then was increased to $95{ }^{\circ} \mathrm{C}$ at a rate of $6{ }^{\circ} \mathrm{C} / \mathrm{min}$, held at $95{ }^{\circ} \mathrm{C}$ for $5 \mathrm{~min}$. After that, starch slurries were cooled to $50{ }^{\circ} \mathrm{C}$ at a rate of $6{ }^{\circ} \mathrm{C} / \mathrm{min}$ and retained at $50{ }^{\circ} \mathrm{C}$ for $2 \mathrm{~min}$. The rotation speeds were kept at $960 \mathrm{rpm}$ for the first $10 \mathrm{~s}$; then, the rotation speeds were reduced to $160 \mathrm{rpm}$ for the remainder of the cycle (Ratnaningsih et al. 2016).

\section{Determination of thermal properties}

The thermal properties of starches were determined using Differential Scanning Calorimetry (DSC-60 Plus, Shimadzu, Japan), which was equipped with TA-60WS software. The sample was weighed, then put into a standard aluminum pan, added with distilled water $(10 \mu \mathrm{l})$, hermetically sealed, stand for at least $1 \mathrm{~h}$ before heating in DSC. The sample pan and reference pan were heated from 25 to $100{ }^{\circ} \mathrm{C}$ at a rate of $10{ }^{\circ} \mathrm{C} / \mathrm{min}$ (Joshi et al. 2013).

\section{Determination of $\mathrm{X}$-ray diffraction and relative crystallinity}

Determination of crystalline structure was performed using an X-Ray Diffractometer (XRD) (Bruker D2 Phaser, Germany) with $\mathrm{CuK} \alpha$ radiation nickel filter $(\lambda=1.542 \AA)$ and operated at $30 \mathrm{kV}$ and $10 \mathrm{~mA}$. Diffractograms were obtained from $4-30^{\circ}$ as a $2 \theta$ function (Kaur and Sandhu 2010). The relative crystallinity was determined according to Wang et al. (2008). The area above the smooth curve was the crystalline portion, and the lower area between the smooth curve and the linear baseline was the amorphous portion. The upper diffraction peak area and overall diffraction area were integrated using the origin software (version 9.65, Microcal Inc., Northampton, MA, USA). The relative crystallinity was calculated based on this equation:

$$
\mathrm{RC}(\%)=\frac{\mathrm{Ac}}{(\mathrm{Ac}+\mathrm{Aa})} \times 100
$$

Where: RC: relative crystallinity; Ac: the crystallized area on the X-ray diffractogram; Aa: the amorphous area on the X-ray diffractogram

\section{Determination of Fourier Transform Infrared (FTIR) spectroscopy}

One milligram of the sample was mixed homogenously with $100 \mathrm{mg}$ dried $\mathrm{KBr}$ powder to form a pellet. $\mathrm{KBr}$ pelletized starch samples were analyzed using FTIR (Nicolet iS 10, Thermo Scientific, USA) in the range of wavenumbers $400-4000 \mathrm{~cm}^{-1}$ (Ratnaningsih et al. 2016).

\section{Data analysis}

The research data were interpreted as mean value \pm standard deviation of triplicate replications, except for SEM and FTIR analysis. Statistical analysis was performed using one-way Analysis of Variance (ANOVA) followed by Duncan's Multiple Range Test (DMRT) to assess the significant differences among experimental mean values $(\mathrm{P}<0.05)$. All statistical analysis was performed using SPSS software version 23.0 (SPSS Inc. Chicago, IL, USA).

\section{RESULTS AND DISCUSSION}

\section{Yield and chemical composition of pigeon pea starches}

The yield and chemical composition of pigeon pea starches are summarized in Table 2. The yield of pigeon pea starches (on a total of pigeon pea seed basis) varied from 29.83-31.68\%, with the highest yield of pigeon pea starch from Bali. Variations in pigeon pea starch yields could be attributed to the drying process of pigeon pea seeds by local farmers using sunlight, which affects the moisture content of pigeon pea seeds. Pigeon pea seeds from Bali had the lowest moisture content (data not shown), and when a grinder splits the seeds, fewer broken seeds into a fine powder were produced, allowing more seeds to be extracted into starch. In this study, pigeon pea starch yield was higher than the yield of pigeon pea starch from Nigeria, 22.5\% (Lawal 2011), but lower than pigeon pea from Argentina, 38.24\% (Acevedo et al. 2019). The moisture content of pigeon pea starches ranged from 8.67$9.32 \%$, meeting the moisture content requirements for powdered dry products, i.e., < 15\% (Estrada-León et al. 2016). The starch purity was assessed from the starch content (Velásquez-Barreto et al. 2021a) and was evaluated based on the low ash, total lipid, and nitrogen content (Ratnaningsih et al. 2016). This starch extraction method produced pigeon pea starches with high purity, consisting of $93.46-94.96 \%$ starch with low protein content $(0.40-$ $0.49 \%)$, lipid content $(0.07-0.34 \%)$, and ash content $(0.04-$ $0.05 \%)$. Pigeon pea starch from NTB achieved the highest purity (highest starch content) because it had the lowest ash, lipid, and protein content, indicating low impurities. According to Ratnaningsih et al. (2016), high purity starch contains $<0.6 \%$ of protein. The low protein content 
indicates the absence of non-starch lipid (endosperm protein-related lipids) (Maaran et al. 2014).

The amylose content of pigeon pea starches was significantly different, varied from 54.74-58.51\%. The highest amylose content was found in Yogyakarta pigeon pea starch. It could be related to the lowest temperature in Yogyakarta. Ovando-Martínez et al. (2011) reported that lower temperature during growing resulted in an increased amylose content in bean starch. The amylose content of Indonesian pigeon pea starches is higher than the pigeon pea starches was reported by Hoover et al. (2010), 27.0$46.4 \%$. However, these values remain within the range of amylose content of legume starches (24-65\%) (Lima et al. 2017). The variations of amylose content can be affected by climate, soil type during plant growth, and growing conditions (Du et al. 2014; Ma et al. 2017). The amylose content of starch is classified into low $(<20 \%)$, medium (20-25\%), and high (>25\%) (Santoso et al. 2021). Thus, pigeon pea starch has a high amylose content, which can indicate its health benefits. There is a strong association between amylose content and the development of resistant starch. Starch digestibility decreases with increased amylose content (Nissar et al. 2017). In addition, amylose content can affect the functional and physicochemical properties of starch.

\section{Granule morphology and size distribution}

Pigeon pea starch granules were oval to elliptical (Figure 1). It is similar to Indian and Nigerian pigeon pea starches (Kaur and Sandhu 2010; Lawal 2011; Acevedo et al. 2019). The surface of the starch granule appeared smooth, although some granules had fissures. These are characteristic of legume starches such as Indian pigeon pea starch (Hoover et al. 1993), field pea starch (Liu et al. 2015), rice bean starch, tepary bean starch, navy bean starch, lablab bean starch (Maaran et al. 2014), and yellow pea starch (Chung and Liu 2012). The deep fissures in pigeon pea starch granules showed a strong bonding between the starch and the protein matrix (Vaz Patto et al. 2015).

Granule size can affect starch physicochemical properties such as crystallinity, pasting, enzyme resistance, and solubility (Ma et al. 2017). Zhang et al. (2016a) reported that larger-sized starch granules have higher amylose content, leading to more defects of the crystalline area, thus resulting in lower relative crystallinity, consistent with our results. The mean granule diameter of pigeon pea starches ranged from 18.41-19.98 $\mu \mathrm{m}$ (Table 2), similar to the Indian pigeon pea starches (19.8-20.2 $\mu \mathrm{m})$ (Kaur and Sandhu 2010). The mean granule diameter of pigeon pea starches was smaller than pinto bean starch $(26.0 \mu \mathrm{m})$, red kidney bean starch $(27.4 \mu \mathrm{m})$, black bean starch $(25.3 \mu \mathrm{m})$, and navy bean starch $(26.6 \mu \mathrm{m})$ (Du et al. 2014). Differences in amylose and amylopectin molecules, climate, and agronomic conditions can influence granule size variations (Ma et al. 2017). Yogyakarta pigeon pea starch had the largest mean granule diameter than the other starches. It showed that higher growing temperature caused the reduction of granule size, in agreement with prior research findings (Beckleas and Thitisaksakul, 2014). Granule size of starch is categorized into large $(>25 \mu \mathrm{m})$, medium $(10-25 \mu \mathrm{m})$, small $(5-10 \mu \mathrm{m})$, and very small $(<5$ $\mu \mathrm{m})$ (Estrada-León et al. 2016). Thus, the pigeon pea starch granules are medium in size. Pigeon pea starch can be used as a large-sized starch blend to achieve the required degree of swelling and viscosity. Large-sized starch granules swell faster, have greater viscosities, and are more susceptible to shear than smaller granules (Otegbayo et al. 2014). Punchaarnon et al. (2008) studied that the blends of canna starch (large size) and mung bean starch (medium size) with 25: 75 and 50: 50 ratios produced lower hardness starch gels than the individual starch components.

\section{Color of pigeon pea starches}

The $L^{*}, a^{*}$, and $b^{*}$ values of the pigeon pea starches varied significantly (Table 3). Among the pigeon pea starches, pigeon pea starch from NTB showed the highest lightness value and whiteness index compared to other starches. This result could be attributed to its highest starch purity, indicating low impurities in pigeon pea starch from NTB. According to Bhat and Riar (2016), starch with a lightness value of more than 90 is essential in determining the whiteness and purity of starch. Pigeon pea starches had a lightness value of 92.38-93.08 and a whiteness index of 91.76-92.74, revealing that they have a white color. A high lightness value and whiteness index are significant quality indicators of starch, and they are desired to fulfill consumer preferences (Zhu et al. 2009; Kim et al. 2018).

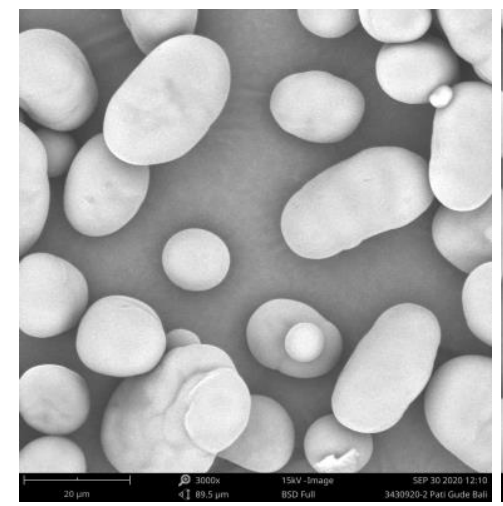

A

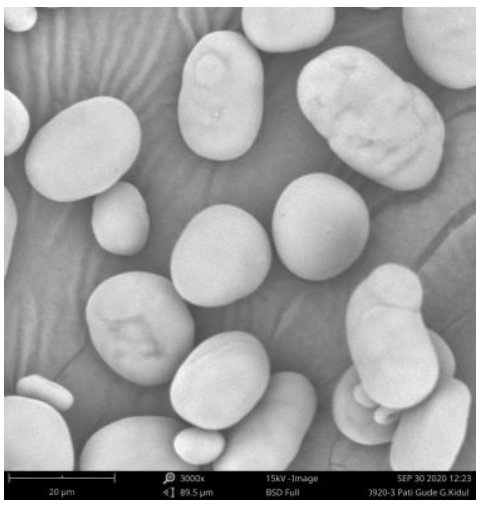

B

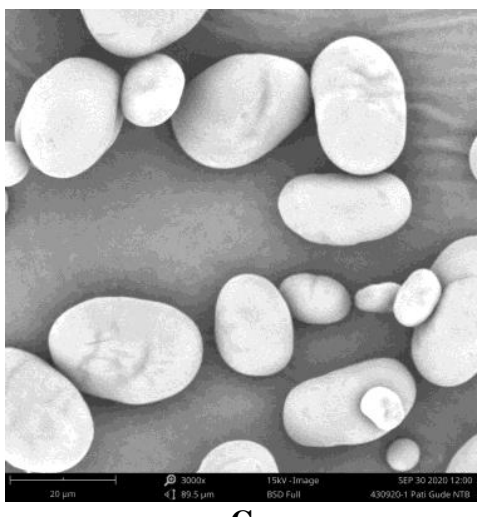

C

Figure 1. Scanning electron micrographs of pigeon pea starches at $3000 \times$ magnification. A. Bali, B. Yogyakarta, C. West Nusa Tenggara (NTB) 
Table 2. Yield, chemical composition, mean granule diameter, and relative crystallinity of pigeon pea starches

\begin{tabular}{lccc}
\hline \multirow{2}{*}{ Parameters } & \multicolumn{3}{c}{ Pigeon pea starches } \\
\cline { 2 - 4 } & Bali & Yogyakarta & NTB \\
\hline Yield $(\% \mathrm{db})$ & $31.68 \pm 0.25 \mathrm{a}$ & $30.31 \pm 0.97 \mathrm{~b}$ & $29.83 \pm 0.59 \mathrm{~b}$ \\
Moisture $(\% \mathrm{db})$ & $9.32 \pm 0.19 \mathrm{a}$ & $9.01 \pm 0.29 \mathrm{ab}$ & $8.67 \pm 0.16 \mathrm{~b}$ \\
Ash $(\% \mathrm{db})$ & $0.05 \pm 0.02 \mathrm{a}$ & $0.04 \pm 0.01 \mathrm{a}$ & $0.04 \pm 0.01 \mathrm{a}$ \\
Protein $(\% \mathrm{db})$ & $0.49 \pm 0.13 \mathrm{a}$ & $0.44 \pm 0.05 \mathrm{a}$ & $0.40 \pm 0.01 \mathrm{a}$ \\
Lipid $\% \mathrm{db})$ & $0.34 \pm 0.07 \mathrm{a}$ & $0.19 \pm 0.03 \mathrm{~b}$ & $0.07 \pm 0.02 \mathrm{c}$ \\
Starch purity $(\% \mathrm{db})$ & $93.46 \pm 0.44 \mathrm{~b}$ & $94.30 \pm 0.83 \mathrm{ab}$ & $94.96 \pm 0.46 \mathrm{a}$ \\
Amylose $(\% \mathrm{db})$ & $56.95 \pm 0.69 \mathrm{~b}$ & $58.51 \pm 0.63 \mathrm{a}$ & $54.74 \pm 0.39 \mathrm{c}$ \\
Mean granule diameter $(\mu \mathrm{m})$ & $18.54 \pm 0.25 \mathrm{~b}$ & $19.98 \pm 0.06 \mathrm{a}$ & $18.41 \pm 0.19 \mathrm{~b}$ \\
Relative crystallinity $(\%)$ & $28.97 \pm 0.65 \mathrm{a}$ & $24.20 \pm 0.70 \mathrm{c}$ & $26.82 \pm 0.50 \mathrm{~b}$ \\
\hline
\end{tabular}

Note: numbers followed by the same letters in the same row indicate not significantly different at $\mathrm{p}<0.05$

Table 3. Color of pigeon pea starches

\begin{tabular}{lccc}
\hline \multirow{2}{*}{ Parameters } & \multicolumn{3}{c}{ Pigeon pea starches } \\
\cline { 2 - 4 } & Bali & Yogyakarta & NTB \\
\hline $\mathrm{L}^{*}$ & $92.81 \pm 0.15 \mathrm{~b}$ & $92.38 \pm 0.03 \mathrm{c}$ & $93.08 \pm 0.03 \mathrm{a}$ \\
$\mathrm{a}^{*}$ & $1.14 \pm 0.06 \mathrm{~b}$ & $1.26 \pm 0.08 \mathrm{a}$ & $1.20 \pm 0.02 \mathrm{ab}$ \\
$\mathrm{b}^{*}$ & $2.45 \pm 0.14 \mathrm{~b}$ & $2.87 \pm 0.08 \mathrm{a}$ & $1.85 \pm 0.11 \mathrm{c}$ \\
Whiteness index & $92.32 \pm 0.10 \mathrm{~b}$ & $91.76 \pm 0.01 \mathrm{c}$ & $92.74 \pm 0.01 \mathrm{a}$ \\
\hline
\end{tabular}

Note: numbers followed by the same letters in the same row indicate not significantly different at $\mathrm{p}<0.05$

The lightness value of pigeon pea starches was nearly equal to cowpea starch (89.9-92.4) and mungbean starch (90.2-92.1) (Kim et al. 2018) but lower than chickpea starch of 98.07 (Bashir and Aggarwal 2017) may be attributed to the existence of phenolic and flavonoid compounds in the pigeon pea. Rani et al. (2014) reported that dehusked dal of pigeon pea has a total phenolic and flavonoid content of $8.07 \mathrm{mgGAE} / \mathrm{g}$ and $4.65 \mathrm{mgCAE} / \mathrm{g}$, respectively, so these compounds can reduce the lightness of the pigeon pea starch. All pigeon pea starches showed a positive value for $\mathrm{a}^{*}$ and $\mathrm{b}^{*}$, suggesting a high intensity of red and yellow, respectively.

\section{Functional properties of pigeon pea starches}

The functional properties of pigeon pea starches are listed in Table 4. The water-binding capacity (WBC) is the indicator of starch's ability to bind restricted water content (Bhat and Riar 2016). WBC of starch can be affected by granule structure variations and the proportion of hydroxyl groups involved in forming covalent and hydrogen bonds between starch chains (Ratnaningsih et al. 2016). The WBC of pigeon pea starches ranged from $0.70-0.76 \mathrm{~g} / \mathrm{g}$, with pigeon pea starch from Bali having the highest WBC. This value was comparable to the $\mathrm{WBC}$ of Indian pigeon pea, 0.65-0.77 g/g (Narina et al. 2014), and cowpea starch $(0.64-0.99 \mathrm{~g} / \mathrm{g})$. Therefore, pigeon pea starches can be applied as a binder agent, such as in sausage products.

The oil binding capacity (OBC) evaluates starch's ability to bind fat physically caused by capillary activity. The OBC of starch has a crucial role in conventional food formulation because it can decide its mouth-feel and flavor enhancement. It also determines the starch's ability to maintain flavor during food preparation (Bhat and Riar 2016). Pigeon pea starches had an OBC range of 0.55-0.58 $\mathrm{g} / \mathrm{g}$, lower than the WBC value. It showed a similar pattern to cowpea starch (Ratnaningsih et al. 2016) but the inverse pattern to rice starch (Bhat and Riar 2016). The availability of water-binding sites, which may explain variations in WBC and OBC of different starches. The OBC of pigeon pea starches was almost identical to cowpea starches (0.47$0.63 \mathrm{~g} / \mathrm{g}$ ) (Ratnaningsih et al. 2016), so it can be applied to the fried food products.

The swelling power shows the extent of water absorption of the granule starch (Fan et al. 2016). The swelling power of pigeon pea starches varied from 13.19$14.52 \mathrm{~g} / \mathrm{g}$, almost the same as Indian pigeon pea starch 12.6-13.1 g/g (Kaur and Sandhu 2010), and including in the range of the swelling power of other legume starches (7.23$25.9 \mathrm{~g} / \mathrm{g}$ ) (Wani et al. 2016). The pigeon pea starch from Yogyakarta had the lowest swelling power, which can be related to Yogyakarta pigeon pea starch having the highest amylose content. Previous research on rice starch, maize starch, and field pea starch have similar results (Huang et al. 2015; Liu et al. 2015). The swelling power is mainly a function of the amylopectin molecule. Amylose acts as a diluting or inhibiting agent for amylopectin swelling (Liu et al. 2015). Huang et al. (2015) reported that swelling power has a negative correlation with amylose content. Swelling power less than $16 \mathrm{~g} / \mathrm{g}$ is considered a highly restricted swelling behavior. It is suitable for application in noodle products (Jan et al. 2017).

Table 4. Functional properties of pigeon pea starches

\begin{tabular}{lccc}
\hline \multirow{2}{*}{$\begin{array}{l}\text { Functional } \\
\text { properties }\end{array}$} & \multicolumn{3}{c}{ Pigeon pea starches } \\
\cline { 2 - 4 } WBC $(\mathrm{g} / \mathrm{g})$ & $0.76 \pm 0.01 \mathrm{a}$ & $0.73 \pm 0.01 \mathrm{~b}$ & $0.70 \pm 0.01 \mathrm{c}$ \\
$\mathrm{OBC}(\mathrm{g} / \mathrm{g})$ & $0.58 \pm 0.01 \mathrm{a}$ & $0.56 \pm 0.01 \mathrm{~b}$ & $0.55 \pm 0.01 \mathrm{~b}$ \\
Swelling power $(\mathrm{g} / \mathrm{g})$ & $14.52 \pm 0.22 \mathrm{a}$ & $13.19 \pm 0.58 \mathrm{~b}$ & $14.13 \pm 0.34 \mathrm{a}$ \\
Solubility $(\%)$ & $11.15 \pm 0.11 \mathrm{a}$ & $9.48 \pm 0.11 \mathrm{~b}$ & $10.98 \pm 0.11 \mathrm{a}$ \\
\hline Note: numbers followed by the same letters in the same row \\
indicate not significantly different at $\mathrm{p}<0.05$. WBC: water- \\
binding capacity, OBC: oil binding capacity
\end{tabular}


The solubility represents the starch dissolution level during the starch's swelling (Fan et al. 2016). The solubility of pigeon pea starches ranged from 9.48-11.15\%, lower than the solubility of Indian pigeon pea starches 13.8$14.2 \%$ (Kaur and Sandhu 2010) and other legume starches (13.1-37.8\%) (Wani et al. 2016). It showed the potential of pigeon pea starches to apply as an edible film. The lowest solubility was found in Yogyakarta pigeon pea starch, which is consistent with its swelling power. The higher the amylose content, the denser the starch granule, making it more difficult for starch to overflow beyond the granule and, as a result, lowering starch solubility (Wani et al. 2012).

\section{Pasting properties}

Pigeon pea starches displayed similarly pasting behavior (Figure 2) but showed distinct characteristics (Table 5), except for final viscosity. The pasting temperature (PT) is the lowest temperature was required to cook the starch $(\mathrm{Ma}$ et al. 2017). The pasting temperature of pigeon pea starches ranged from $82.27-83.38^{\circ} \mathrm{C}$, compatible with the pasting temperature of Indian pigeon pea starches (82.0-83.9 ${ }^{\circ} \mathrm{C}$ ) (Kaur and Sandhu 2010) and Argentina's pigeon pea starch $\left(83.9{ }^{\circ} \mathrm{C}\right.$ ) (Acevedo et al. 2019). Yogyakarta pigeon pea starch showed the highest pasting temperature, suggesting that it is more resistant to swelling, consistent with its lowest swelling power. It may be attributed to the high content of amylose in Yogyakarta pigeon pea starch. Huang et al. (2015) reported that high-amylose starch has a higher pasting temperature than normal-amylose starch.
The peak viscosity (PV) indicates the maximum viscosity obtained by gelatinized starch when heated in water (Bhat and Riar 2016). The Peak viscosity of pigeon pea starch was 5252.00, 5912.33, and 5925.00 cP for Bali, Yogyakarta, and NTB. Pigeon pea starch from Bali showed the lowest peak viscosity, attributed to its highest relative crystallinity (Ovando-Martínez et al. 2011) and its lowest starch content (Grace and Henry 2020). The peak viscosity of pigeon pea starches was higher than field pea starches (2119-2805 cP) (Liu et al. 2015) and cowpea starches (1743.50-2036.00 cP) (Ratnaningsih et al. 2016), so pigeon pea starch can be applied in the very viscous paste. Variations in peak viscosity of starches can be linked to amylopectin and amylose molecular weights and amylopectin chain length. Velásquez-Barreto et al. (2021a) reported the positive correlation between peak viscosity with the amylopectin and amylose molecular weight and the amylopectin chain length of B2 (DP 25-36).

The breakdown viscosity (BV) measures the extent of the granule's destruction and indicates the paste's consistency (Fan et al. 2016). The breakdown viscosity of pigeon pea starches ranged from 1327.33-1773.00 cP, higher than Indian pigeon pea starches (Kaur and Sandhu 2010), field pea starches (504-891 cP) (Liu et al. 2015), and cowpea starches (380.00-634.50 cP) (Ratnaningsih et al. 2016). Pigeon pea starch from Bali had the lowest breakdown viscosity. It showed a strong, cohesive force inside the starch granule, excellent thermal and shear stress stability than the others (Ratnaningsih et al. 2016; Ma et al. 2017).

Table 5. Pasting properties of pigeon pea starches

\begin{tabular}{lccc}
\hline \multirow{2}{*}{ Pasting properties } & \multicolumn{3}{c}{ Pigeon pea starches } \\
\cline { 2 - 4 } & Bali & Yogyakarta & NTB \\
\hline PT $\left({ }^{\circ} \mathrm{C}\right)$ & $82.38 \pm 0.08 \mathrm{~b}$ & $83.38 \pm 0.20 \mathrm{a}$ & $82.27 \pm 0.19 \mathrm{~b}$ \\
PV (cP) & $5252.00 \pm 166.23 \mathrm{~b}$ & $5912.33 \pm 32.87 \mathrm{a}$ & $5925.00 \pm 130.09 \mathrm{a}$ \\
TV (cP) & $3924.67 \pm 140.36 \mathrm{~b}$ & $4139.33 \pm 13.65 \mathrm{a}$ & $4281.00 \pm 67.85 \mathrm{a}$ \\
BV (cP) & $1327.33 \pm 25.89 \mathrm{c}$ & $1773.00 \pm 46.36 \mathrm{a}$ & $1644.00 \pm 62.48 \mathrm{~b}$ \\
FV (cP) & $7859.67 \pm 333.62 \mathrm{a}$ & $7709.33 \pm 12.50 \mathrm{a}$ & $8129.33 \pm 273.13 \mathrm{a}$ \\
SV (cP) & $3935.00 \pm 193.75 \mathrm{a}$ & $3570.00 \pm 13.23 \mathrm{~b}$ & $3848.33 \pm 208.01 \mathrm{ab}$ \\
\hline
\end{tabular}

Note: numbers followed by the same letters in the same row indicate not significantly different at $\mathrm{p}<0.05$. PT: pasting temperature, PV: peak viscosity, TV: through viscosity, BV: breakdown viscosity, FV: final viscosity, SV: setback viscosity

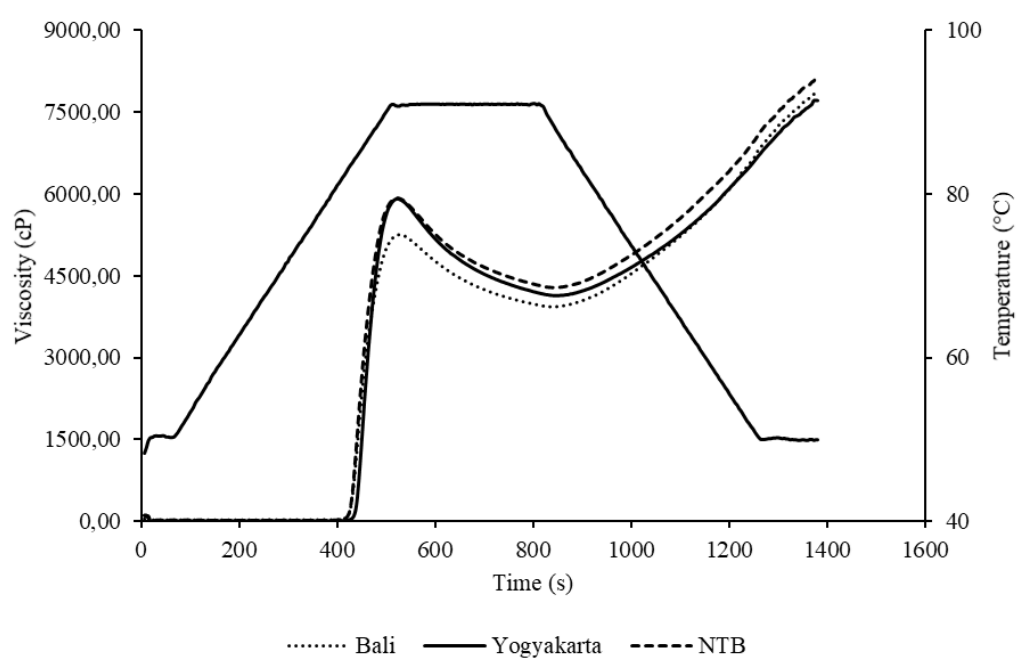

Figure 2. Pasting behavior of pigeon pea starches 
Since pigeon pea starches have a relatively high breakdown viscosity, they are unsuitable for food products that require high temperature and shear stress during production. The final viscosity (FV) shows the amylose molecule's re-assembly to form a gel (Zhang et al. 2016b). The final viscosity of pigeon pea starches ranged from 7709.33-8129.33 cP, higher than other legume starches (2721-7297 cP) (Wani et al. 2016). According to GutiérrezCortez et al. (2021), starch with a high final viscosity behaves as a custard, making pigeon pea starches suitable for infantile formulations. Velásquez-Barreto et al. (2021a) and Liu et al. (2015) reported that higher final viscosity could be linked to higher amylose content. This tendency contradicted the findings of this study; Ratnaningsih et al. (2016); Bhat and Riar (2016). These results suggested that amylose is not the only factor that may affect final viscosity. Velásquez-Barreto et al. (2021b) reported that the presence of granules or small disintegrated granules in the starch paste increases final viscosity.

The Setback viscosity (SV) is the difference between final and through viscosity (TV) and reflects a tendency for starch to retrograde. It measures the gelatinized starch's recrystallization during the cooling process (Bhat and Riar 2016). The setback viscosity of pigeon pea starches varied from 3570.00-3935.00 cP, higher than lablab bean starch (2755 cP), navy bean starch $(1858 \mathrm{cP})$, rice bean starch (2930 cP), tepary bean starch $(1608 \mathrm{cP})$, velvet bean starch (1921 cP) (Maaran et al. 2014), but still included in the range setback viscosity of legume starches (834-4391 cP) (Wani et al. 2016). Since pigeon pea starches have a high setback viscosity, it is not appropriate for frozen food products. The lowest setback viscosity of Yogyakarta pigeon pea starch represented extensive granule disturbance during the heating period, as seen in the high peak viscosity. Therefore, it makes the resistance to the paddles stirring motion during the cooling period minimum, as reported by Ratnaningsih et al. (2016) on the Indonesian cowpea starches. The interaction of many factors can influence the differences in starch pasting properties. These factors: starch purity, granule size, amylose content, amylose/amylopectin ratio, thermal and shear stress stability, interactions between double helices in granules, granule swelling, the chain length of the starch component, and relative crystallinity (Ratnaningsih et al. 2016; Ma et al. 2017).

\section{Thermal properties}

The thermal properties of pigeon pea starches are listed in Table 6. The gelatinization temperatures, i.e., onset temperature (To), peak temperature (Tp), conclusion temperature (Tc) of pigeon pea starches, varied from 75.7876.47 ${ }^{\circ} \mathrm{C}, \quad 81.38-82.50{ }^{\circ} \mathrm{C}$, and 85.31-86.68 ${ }^{\circ} \mathrm{C}$, respectively. Indonesian pigeon pea starches had higher gelatinization temperatures than Indian pigeon pea starches (Kaur and Sandhu 2010; Narina et al. 2014) and Argentina's pigeon pea starch (Acevedo et al. 2019). The variations of gelatinization temperatures can be related to some factors. These factors are amylopectin's branch-chain length, granule architecture, amylose content, and amylose- lipid complex (Du et al. 2014). The gelatinization enthalpy $(\Delta \mathrm{H})$ of pigeon pea starches ranged from $9.15-10.00 \mathrm{~J} / \mathrm{g}$. It was similar to the Indian pigeon pea starch's gelatinization enthalpy, 8.8-9.2 J/g (Kaur and Sandhu 2010). Yogyakarta pigeon pea starch's peak temperature was the highest, which correlates to its high pasting temperature. Pigeon pea starch from Yogyakarta had the highest-conclusion temperature, which may be related to its highest amylose content and its largest granule size. Higher amylose content leads to retardation of swelling and gelatinization (Chung et al. 2011). Larger granules have a lower hydration and swelling capacity than smaller granules (Grace and Henry 2020)

\section{XRD pattern of pigeon pea starches}

Pigeon pea starches had a similar XRD pattern (Figure 3). Starch diffraction patterns can be classified into three categories: A, B, and C. A-type starch has strong diffraction peaks at about $15^{\circ}$ and $23^{\circ} 2 \theta$, and an unresolved doublet at around $17^{\circ}$ and $18^{\circ} 2 \theta$. B-type starch shows the strongest peak at around $17^{\circ} 2 \theta$ and small peaks at about $5.6^{\circ}, 15^{\circ}, 20^{\circ}, 22^{\circ}, 24^{\circ} 2 \theta$. C-type starch is a mixture of A and B-type starch. C-type starch has singlet peaks at around $17^{\circ}$ and $23^{\circ} 2 \theta$ and a few small peaks at about $5.6^{\circ}$ and $15^{\circ} 2 \theta$. It can be further categorized as $\mathrm{C}_{\mathrm{A}}$ type (closer to A-type), C-type, and $\mathrm{C}_{\mathrm{B}}$ (closer to B-type) by the proportion of allomorphs of type $\mathrm{A}$ and type $\mathrm{B}$. The

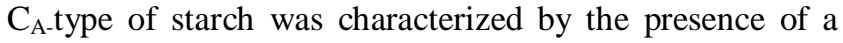
shoulder peak at about $18^{\circ} 20$ and a strong singlet peak at

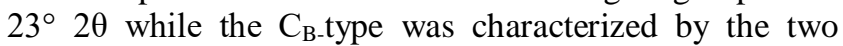
shoulder peaks of about $22^{\circ}$ and $24^{\circ} 2 \theta$ (Cai et al. 2014). According to the XRD pattern, pigeon pea starches showed a peak of diffractogram at around $15^{\circ}, 17^{\circ}, 23^{\circ} 2 \theta$, a small peak at around $5.6^{\circ} 2 \theta$ and a shoulder peak at about $18^{\circ} 2 \theta$. It indicated that pigeon pea starches have a type $\mathrm{C}_{\mathrm{A}}$ diffraction pattern. Rodriguez-Garcia et al. (2021) reported that the XRD diffractogram peaks can determine the crystalline phase of starch. A peak at about $5.6^{\circ} 2 \theta$ shows that pigeon pea starches contain hexagonal phase, while peaks at around $15^{\circ}, 17^{\circ}, 18^{\circ}$, and $23^{\circ} 2 \theta$ show that pigeon pea starches contain orthorhombic phase. Hence, pigeon pea starches contained hexagonal and orthorhombic crystals.

Table 6. Thermal properties of pigeon pea starches

\begin{tabular}{llcl}
\hline Thermal & \multicolumn{3}{c}{ Pigeon pea starches } \\
\cline { 2 - 4 } properties & \multicolumn{1}{c}{ Bali } & \multicolumn{1}{c}{ Yogyakarta } & NTB \\
\hline $\mathrm{To}\left({ }^{\circ} \mathrm{C}\right)$ & $76.47 \pm 0.48 \mathrm{a}$ & $75.78 \pm 0.68 \mathrm{a}$ & $76.29 \pm 0.29 \mathrm{a}$ \\
$\mathrm{Tp}\left({ }^{\circ} \mathrm{C}\right)$ & $81.71 \pm 0.09 \mathrm{~b}$ & $82.50 \pm 0.31 \mathrm{a}$ & $81.38 \pm 0.27 \mathrm{~b}$ \\
$\mathrm{Tc}\left({ }^{\circ} \mathrm{C}\right)$ & $86.34 \pm 0.35 \mathrm{ab}$ & $86.68 \pm 0.83 \mathrm{a}$ & $85.31 \pm 0.17 \mathrm{~b}$ \\
$\Delta \mathrm{H}(\mathrm{J} / \mathrm{g})$ & $10.00 \pm 0.80 \mathrm{a}$ & $9.17 \pm 0.95 \mathrm{a}$ & $9.15 \pm 1.32 \mathrm{a}$ \\
\hline
\end{tabular}

Note: Numbers followed by the same letters in the same row indicate not significantly different at $p<0.05$. To: onset temperature, Tp: peak temperature, Tc; conclusion temperature, $\Delta \mathrm{H}$ : gelatinization enthalpy 


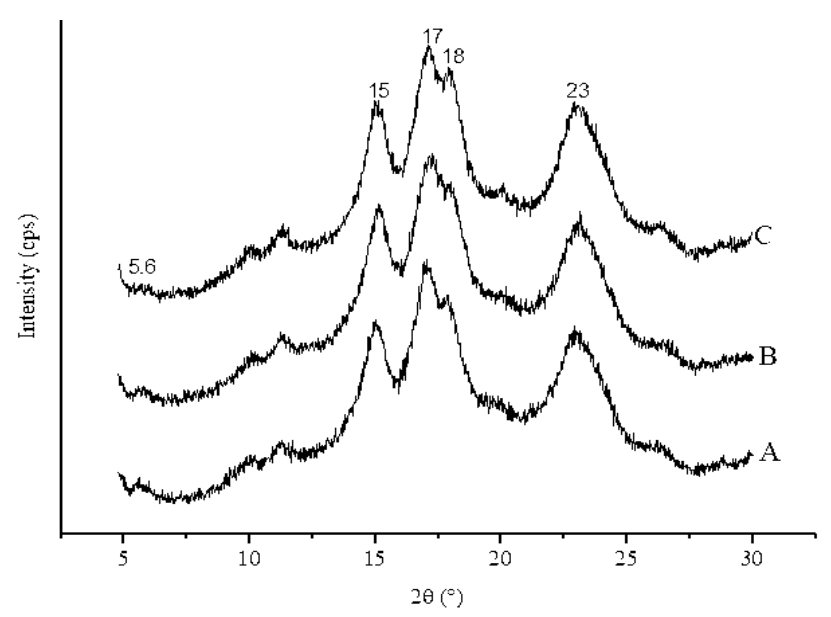

Figure 3. XRD pattern of pigeon pea starches. A. Yogyakarta, B. West Nusa Tenggara, C. Bali

The relative crystallinity of the Yogyakarta pigeon pea starch was the lowest than the other starches (Table 2). Its highest amylose content can explain this result in comparison to Bali and NTB pigeon pea starches. Because the amylopectin side chains form a crystalline structure in starch, the relative crystallinity is inversely related to amylose content (Kaur and Sandhu 2010; Joshi et al. 2013; Oyeyinka et al. 2016). The lowest relative crystallinity of Yogyakarta pigeon pea starch could be attributed to the highest rainfall in the growing location, as reported by Wen et al. (2014) on the proso millet starch. An increase in humidity can disturb the crystalline arrangement of starches, resulting in a weak intensity (Wen et al. 2014). Pigeon pea starch from Bali had the highest relative crystallinity, suggesting better crystallite orientation to the $\mathrm{X}$-ray beam and stronger interaction between double helices inside crystalline lamellae. It is consistent with its lowest breakdown viscosity.

\section{FTIR spectroscopy}

FTIR spectra displayed similar characteristics in all pigeon pea starches (Figure 4). The band at around 3421 $\mathrm{cm}^{-1}$ correlated to the $\mathrm{OH}$ group's stretching, while the band at about $2931 \mathrm{~cm}^{-1}$ related to the stretching vibration of the $\mathrm{CH}_{2}$ bond (Ratnaningsih et al. 2016). The band was detected at about $1649 \mathrm{~cm}^{-1}$ associated with bending $\mathrm{H}_{2} \mathrm{O}$ vibrations absorbed in the amorphous regions of starch (Oyeyinka et al. 2016). According to Shao et al. (2020), the band at about $1082 \mathrm{~cm}^{-1}$ and $1160 \mathrm{~cm}^{-1}$ were associated with the $\mathrm{C}-\mathrm{O}$ group's vibrational and the symmetrical stretching vibration of $\mathrm{CH}_{2}$, linked to the starch's ordered structure. The band at around $1014 \mathrm{~cm}^{-1}$ was characteristic of an amorphous region of starch (Joshi et al. 2013). The band at about $860 \mathrm{~cm}^{-1}$ could be attributed to C-O-C symmetrical stretching and $\mathrm{C}-\mathrm{H}$ deformation (Monteiro et al. 2016). The band at around $929 \mathrm{~cm}^{-1}$ could be related to water and starch hydrophilicity (Ratnaningsih et al. 2016; Shao et al. 2020), so this band showed the water-binding capacity of pigeon pea starches (Ratnaningsih et al. 2020). The bands in the $800-400 \mathrm{~cm}^{-1}$ range were correlated with the pyranose ring skeletal mode (Jan et al. 2017).

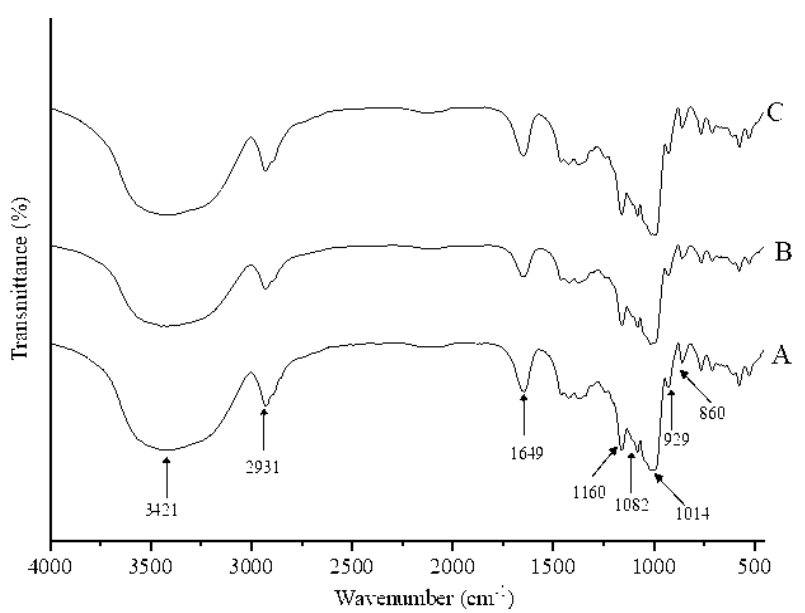

Figure 4. FTIR spectra of pigeon pea starches. A. Yogyakarta, B. West Nusa Tenggara, C. Bali

In conclusion, pigeon pea starch from three different Indonesian regions showed significant differences in amylose content, granule size, and relative crystallinity. Furthermore, these differences affect the physicochemical properties of pigeon pea starch. However, pigeon pea starch showed the same granule shape, X-ray diffraction pattern, and FTIR spectra. Pigeon pea starch from Yogyakarta had the highest amylose content and the lowest relative crystallinity. Based on the pasting properties, pigeon pea starch from NTB showed a low pasting temperature, a high peak viscosity, and a high final viscosity, making it suitable for viscous paste products, and infantile formulations. Further study on physical, enzymatic, chemical, or combination modifications of pigeon pea starch will be required to develop its applicability in diverse food formulations.

\section{ACKNOWLEDGEMENTS}

The authors gratefully acknowledge to Agency for Agricultural Extension and Human Resources Development, Ministry of Agriculture, the Republic of Indonesia for the doctoral program scholarship. The authors also thank the Rekognisi Tugas Akhir (RTA) program of Universitas Gadjah Mada, Yogyakarta for this experiment's financial support.

\section{REFERENCE}

Acevedo BA, Villanueva M, Chaves MG, Avanza MV, Ronda F. 2019. Starch enzymatic hydrolysis, structural, thermal and rheological properties of pigeon pea (Cajanus cajan) and dolichos bean (Dolichos lab-lab) legume starches. Intl J Food Sci Technol 55 (2): 712-719. DOI: $10.1111 /$ ijfs. 14334 .

Alcázar-Alay SC, Meireles MAA. 2015. Physicochemical properties, modifications and applications of starches from different botanical sources. Food Sci Technol 35 (2): 215-236. DOI: 10.1590/1678457X.6749.

AOAC. 1995. Official Methods of Analysis of AOAC International. 16 ${ }^{\text {th }}$. AOAC International, Washington. 
Bashir K, Aggarwal M. 2017. Physicochemical, thermal and functional properties of gamma irradiated chickpea starch. Intl J Biol Macromol 97: 426-433. DOI: 10.1016/j.ijbiomac.2017.01.025.

Beckles DM, Thitisaksakul M. 2014. How environmental stress affects starch composition and functionality in cereal endosperm. Starch /Stärke 66 (1-2): 58-71. DOI: 10.1002/star.201300212.

Bhat FM, Riar CS. 2016. Effect of amylose, particle size \& morphology on the functionality of starches of traditional rice cultivars. Intl J Biol Macromol 92: 637-644. DOI: 10.1016/j.ijbiomac.2016.07.078.

BPS-Statistics Indonesia. 2020. Statistical yearbook of Indonesia 2020 BPS-Statistics Indonesia, Jakarta.

Cai J, Cai C, Man J, Zhou W, Wei C. 2014. Structural and functional properties of C-type starches. Carbohydr Polym 101: 289-300. DOI: 10.1016/j.carbpol.2013.09.058.

Chen Q, Yu H, Wang L, Abdin Z, Chen, Y, Wang J, Zhou W, Yang X, Khan RU, Zhang H, Chen X. 2015. Recent progress in chemical modification of starch and its applications. RSC Adv 5 (83): 6745967474. DOI: $10.1039 / \mathrm{c} 5 \mathrm{ra10849g}$.

Chung HJ, Liu Q. 2012. Physicochemical properties and in vitro digestibility of flour and starch from pea (Pisum sativum L.) cultivars. Intl J Biol Macromol 50 (1): 131-137. DOI 10.1016/j.ijbiomac.2011.10.004.

Chung HJ, Liu Q, Lee L, Wei D. 2011. Relationship between the structure, physicochemical properties and in vitro digestibility of rice starches with different amylose content. Food Hydrocoll 25: 968-975.

Du SK, Jiang H, Ai Y, Jane JL. 2014. Physicochemical properties and digestibility of common bean (Phaseolus vulgaris L.) starches. Carbohydr Polym 108 (1): 200-205. DOI: 10.1016/j.carbpol.2014.03.004

Estrada-León RJ, Moo-Huchin VM, Ríos-Soberanis CR, BetancurAncona D, May-Hernández LH, Carrillo-Sánchez FA, Cervantes-Uc JM, Pérez-Pacheco E. 2016. The effect of isolation method on properties of parota (Enterolobium cyclocarpum) starch. Food Hydrocoll 57: 1-9. DOI: 10.1016/j.foodhyd.2016.01.008.

Fan X, Zhang S, Lin L, Zhao L, Liu A, Wei C. 2016. Properties of new starches from tubers of Arisaema elephas, yunnanense and erubescens. Food Hydrocoll 61: 183-190. DOI: 10.1016/j.foodhyd.2016.05.015.

Grace NCF, Henry CJ. 2020. The physicochemical characterization of unconventional starches and flours used in Asia. Foods 9: 1-12. DOI 10.3390/foods 9020182

Gunaratne A, Bentota A, Cai YZ, Collado L, Corke H. 2011. Functional, digestibility, and antioxidant properties of brown and polished rice flour from traditional and new-improved varieties grown in Sri Lanka. Starch/ Stärke 63 (8): 485-492. DOI: 10.1002/star.201000105.

Gutiérrez-Cortez E，Hernadez-Becerra E， Londoño-Restrepo SM Rodriguez-Garcia ME. 2021. Physicochemical characterization of Amaranth starch insulated by mechanical separations. Intl J Biol Macromol 177: xxx. DOI: 10.1016/j.ijbiomac.2021.02.138.

Hood-Niefer SD, Warkentin TD, Chibbar RN, Vandenberg A, Tyler RT 2012. Effect of genotype and environment on the concentrations of starch and protein in, and the physicochemical properties of starch from, field pea and faba bean. J Sci Food Agric 92 (1): 141-150. DOI: $10.1002 /$ jsfa.4552.

Hoover R, Hughes T, Chung HJ, Liu Q. 2010. Composition, molecular structure, properties, and modification of pulse starches: a review. Food Res Intl 43 (2): 399-413. DOI: 10.1016/j.foodres.2009.09.001.

Hoover R, Swamidas G, Vasanthan T. 1993. Studies on the physicochemical properties of native, defatted, and heat-moisture treated pigeon pea (Cajanus cajan L) starch. Carbohydr Res 246 (1): 185-203. DOI: 10.1016/0008-6215(93)84032-2.

Huang J, Shang Z, Man J, Liu Q, Zhu C, Wei C. 2015. Comparison of molecular structures and functional properties of high-amylose starches from rice transgenic line and commercial maize. Food Hydrocoll 46: 172-179. DOI: 10.1016/j.foodhyd.2014.12.019.

Jan KN, Panesar PS, Rana JC, Singh S. 2017. Structural, thermal and rheological properties of starches isolated from Indian quinoa varieties. Intl $\mathrm{J}$ Biol Macromol 102: 315-322. DOI: 10.1016/j.ijbiomac.2017.04.027

Joshi M, Aldred P, McKnight S, Panozzo, JF, Kasapis S, Adhikari R, Adhikari B. 2013. Physicochemical and functional characteristics of lentil starch. Carbohydr Polym 92: 1484-1496. DOI: 10.1016/j.carbpol.2012.10.035.

Juliano BO. 1971. A Simplified assay for milled-rice amylose. Cereal Sci Today 16 ((11): 334-340
Kaur M, Sandhu KS. 2010. In vitro digestibility, structural and functional properties of starch from pigeon pea (Cajanus cajan) cultivars grown in India. Food Res Intl 43 (1): 263-268. DOI: 10.1016/j.foodres.2009.09.027.

Kim YY, Woo KS, Chung HJ. 2018. Starch characteristics of cowpea and mungbean cultivars grown in Korea. Food Chem 263: 104-111 DOI: 10.1016/j.foodchem.2018.04.114.

Lawal OS. 2011. Hydroxypropylation of pigeon pea (Cajanus cajan) starch: Preparation, functional characterizations and enzymatic digestibility. LWT-Food Sci Technol 44 (3): 771-778. DOI: 10.1016/j.lwt.2010.05.025.

Lima KO, Biduski B, da Silva WMF, Ferreira SM, Pereira Montenegro LM, Dias ARG, Bianchini D. 2017. Incorporation of tetraethylorthosilicate (TEOS) in biodegradable films based on bean starch (Phaseolus vulgaris). Eur Polym J 89: 162-173. DOI: 10.1016/j.eurpolymj.2017.02.008.

Liu C, Wang S, Copeland L, Wang S. 2015. Physicochemical properties and in vitro digestibility of starches from field peas grown in China. LWT-Food Sci Technol 64 (2): 829-836. DOI: 10.1016/j.lwt.2015.06.060.

Ma M, Wang Y, Wang M, Jane J, Du S. 2017. Physicochemical properties and in vitro digestibility of legume starches. Food Hydrocoll 63: 249255. DOI: 10.1016/j.foodhyd.2016.09.004

Maaran S, Hoover R, Donner E, Liu Q. 2014. Composition, structure, morphology and physicochemical properties of lablab bean, navy bean, rice bean, tepary bean and velvet bean starches. Food Chem 152: 491-499. DOI: 10.1016/j.foodchem.2013.12.014.

Monteiro S, Martins J, Magalhães FD, Carvalho L. 2016. Low density wood-based particleboards bonded with foamable sour cassava starch: preliminary studies. Polymers 8: 1-11. DOI: 10.3390/polym8100354.

Narina SS, Bhardwaj HL, Hamama AA, Burke JJ, Pathak SC, Xu Y. 2014. Seed protein and starch qualities of drought tolerant pigeon pea and native tepary beans. J Agric Sci 6 (11): 247-259. DOI: $10.5539 /$ jas.v6n1 1p247

Nissar J, Ahad T, Naik HR, Hussain SZ. 2017. Resistant starch- chemistry and nutritional properties. Intl J Food Sci Nutr 2 (6): 95-108.

Otegbayo B, Oguniyan D, Akinwumi O. 2014. Physicochemical and functional characterization of yam starch for potential industrial applications. Starch/ Stärke 66: 235-250. DOI: 10.1002/star.201300056.

Ovando-Martínez M, Bello-Pérez LA, Whitney K, Osorio-Díaz P, Simsek S. 2011. Starch characteristics of bean (Phaseolus vulgaris L.) grown in different localities. Carbohydr Polym 85: 54-64.

Oyeyinka SA, Singh S, Amonsou EO. 2016. Physicochemical properties of starches extracted from bambara groundnut landraces. Starch/ Stärke 68: 1-8. DOI: 10.1002/star.201600089.

Puncha-arnon S, Pathipanawat W, Puttanlek C, Rungsardthong V, Uttapap D. 2008. Effects of relative granule size and gelatinization temperature on paste and gel properties of starch blends. Food Res Intl 41: 552-561. DOI: 10.1016/j.foodres.2008.03.012

Rani S, Poswal G, Yadav R, Deen MK. 2014. Screening of pigeon pea (Cajanus cajan L.) seeds for study of their flavonoids, total phenolic content and antioxidant properties. Intl J Pharm Sci Rev Res 28 (2): 90-94.

Ratnaningsih N, Suparmo, Harmayani E, Marsono Y. 2016. Composition, microstructure, and physicochemical properties of starches from Indonesian cowpea (Vigna unguiculata) varieties. Intl Food Res J 23 (5): 2041-2049.

Ratnaningsih N, Suparmo, Harmayani E, Marsono Y. 2020. Physicochemical properties, in vitro starch digestibility, and estimated glycemic index of resistant starch from cowpea (Vigna unguiculata) starch by autoclaving-cooling cycles. Intl J Biol Macromol 142: 191200. DOI: 10.1016/j.ijbiomac.2019.09.092.

Rodriguez-Garcia ME, Hernandez-Landaverde MA, Delgado JM, Ramirez-Gutierrez CF, Ramirez-Cardona M, Millan-Malo BM, Londoño-Restrepo SM. 2021. Crystalline structures of the main components of starch. Curr Opin Food Sci 37: 107-111. DOI: 10.1016/j.cofs.2020.10.002.

Santoso B, Sarungallo ZL, Puspita AM. 2021. Physicochemical and functional properties of spineless, short-spines, and long-spines sago starch. Biodiversitas 22 (1): 137-143. DOI: 10.13057/biodiv/d220119.

Shao Y, Mao L, Guan W, Wei X, Yang Y, Xu F, Li Y, Jiang Q. 2020. Physicochemical and structural properties of low-amylose Chinese yam (Dioscorea opposita Thunb.) starches. Intl J Biol Macromol 164: 427-433. DOI: 10.1016/j.ijbiomac.2020.07.054. 
Tayade R, Kulkarni KP, Jo H, Song JT, Lee JD. 2019. Insight into the prospects for the improvement of seed starch in legume - a review. Front Plant Sci 10: 1213. DOI: 10.3389/fpls.2019.01213.

Vaz Patto MC, Amarowicz R, Aryee ANA, Boye JI, Chung HJ, MartínCabrejas MA, Domoney C. 2015. Achievements and challenges in improving the nutritional quality of food legumes. CRC Crit Rev Plant Sci 34: 105-143. DOI: 10.1080/07352689.2014.897907.

Velásquez-Barreto FF, Bello-Pérez LA, Nuñez-Santiago C, Yee-Madeira H, Sánchez CEV. 2021a. Relationships among molecular, physicochemical and digestibility characteristics of Andean tuber starches. Intl J Biol Macromol 182: 472-481. DOI: 10.1016/j.ijbiomac.2021.04.039.

Velásquez-Barreto FF, Miñano HA, Alvarez-Ramirez J, Bello-Pérez LA 2021b. Structural, functional, and chemical properties of small starch granules: Andean quinoa and kiwicha. Food Hydrocoll 120: 106883. DOI: 10.1016/j.foodhyd.2021.106883.

Wang X, Wenyuan G, Liming Z, Peigen X, Liping Y, Yi L, Kefeng L, Weiguang X. 2008. Study on the morphology, crystalline structure and thermal properties of yam starch acetates with different degrees of substitution. Sci China Ser B-Chem 51 (9): 859-865. DOI 10.1007/s11426-008-0089-1.

Wani AA, Singh P, Shah MA, Schweiggert-Weisz U, Gul K, Wani IA 2012. Rice starch diversity: effects on structural, morphological, thermal, and physicochemical properties-A Review. Compr Rev Food
Sci Food Saf $11 \quad$ (5): 417-436. DOI: 10.1111/j.15414337.2012.00193.x.

Wani IA, Sogi DS, Hamdani AM, Gani A, Bhat NA, Shah A. 2016. Isolation, composition, and physicochemical properties of starch from legumes: a review. Starch/Stärke 68 (9-10): 834-845. DOI: 10.1002/star.201600007.

Wen Y, Liu J, Meng X, Zhang D, Zhao G. 2014. Characterization of proso millet starches from different geographical origins of China. Food Sci Biotechnol 23 (5): 1371-1377. DOI: 10.1007/s10068-014-0188-z.

Widowati S, Buckle KA. 1991. Sifat-sifat fisik dan mikroskopis pati gude (Cajanus cajan (L) Millsp). Agritech 11 (2): 2-6. [Indonesian].

Yousif EI, Gadallah MGE, Sorour AM. 2012. Physico-chemical and rheological properties of modified corn starches and its effect on noodle quality. Ann Agric Sci 57 (1): 19-27. DOI: 10.1016/j.aoas.2012.03.008

Zhang Y, Guo Q, Nan F, et al. 2016a. Characterization of A- and B- type starch granules in Chinese wheat cultivars. J Integr Agric 15(0): 60345-7. DOI: 10.1016/S2095-3119(15)61305-3.

Zhang Y, Zhu K, He S, Tan L, Kong X. 2016b. Characterizations of high purity starches isolated from five different jackfruit cultivars. Food Hydrocoll 52: 785-794. DOI: 10.1016/j.foodhyd.2015.07.037.

Zhu K, Kanu PJ, Claver IP, Zhu K, Qian H, Zhou H. 2009. A method for evaluating hunter whiteness of mixed powders. Adv Powder Technol 20: 123-126. DOI: 10.1016/j.apt.2008.04.001. 